\title{
PENINGKATAN KEMAMPUAN MEMBACA PEMAHAMAN TEKS NARASI MELALUI STRATEGI PREVIEW, QUESTION, READ, REFLECT, RECITE, REVIEW (PQ4R) SISWA KELAS V $V_{B}$ SDN 4 RANOMEETO
}

\author{
Lilis Apriyani ${ }^{1)}$, La Rabani ${ }^{1)}$, Mansyur $\mathrm{M}^{1}$ \\ ${ }^{1)}$ Jurusan Pendidikan Guru Sekolah Dasar \\ FKIP Universitas Halu Oleo \\ Email: lilisapriyani.020@yahoo.com, 1arabani59@gmail.com, mansyurm919@gmail.com
}

\begin{abstract}
Abstrak: Penelitian ini di latar belakangi dari rendahnya kemampuan membaca pemahaman siswa pada mata pelajaran bahasa indonesia. Rendahnya kemampuan membaca pemahaman siswa karena dalam proses pembelajaran guru masih menggunakan metode konvensional dan belum pernah menggunakan strategi yang tepat untuk mempermudah siswa dalam memahami dan mengingat suatu bacaan. Rumusan masalah dalam penelitian ini adalah; Apakah strategi Preview, Question, Read, Reflect, Recite, Review (PQ4R) dapat meningkatkan kemampuan membaca pemahaman teks narasi pada Tema Peristiwa dalam Kehidupan siswa kelas $V_{B}$ di SDN 4 Ranomeeto? Penelitian ini bertujuan; Untuk meningkatkan hasil belajar siswa dalam kemampuan membaca pemahaman teks narasi pada tema 7 peristiwa dalam kehidupan siswa kelas $\mathrm{V}_{\mathrm{B}}$ di SDN 4 Ranomeeto melalui strategi Preview, Question, Read, Reflect, Recite, Review (PQ4R); Penelitian ini dilaksanakan dalam dua siklus. Subjek penelitian adalah siswa kelas $\mathrm{V}_{\mathrm{B}}$ di SDN 4 Ranomeeto tahun ajaran 2019/2020 sebanyak 28 siswa. Penelitian ini difokuskan kepada peningkatan kemampuan membaca pemahaman siswa setelah menerapkan strategi Preview, Question, Read, Reflect, Recite, Review (PQ4R). Teknik pengumpulan data menggunakan observasi, tes, dan dokumentasi. Teknik analisis data menggunakan analisis deskriptif kuantitatif dan kualitatif. Peningkatan proses pembelajaran dapat dilihat dari peningkatan kemampuan membaca pemahaman siswa kelas $\mathrm{V}_{\mathrm{B}}$ dengan ketuntasan belajar siswa mencapai $57,14 \%$ dengan rata-rata nilai siswa sebesar 59,0 pada siklus I. Sedangkan pada siklus II mencapai $78,57 \%$ dengan rata-rata nilai siswa mencapai 78,96. Berdasarkan Hasil penelitian tersebut dapat disimpulkan bahwa strategi Preview, Question, Read, Reflect, Recite, Review (PQ4R) dapat meningkatkan proses pembelajaran dan kemampuan membaca pemahaman teks narasi pada siswa kelas $V_{B}$ SDN 4 Ranomeeto.
\end{abstract}

Kata kunci: Kemampuan Membaca Pemahaman; Teks Narasi, Strategi Preview; Question Read Reflect Recite Review (PQ4R)

\section{IMPROVED READING ABILITY OF TEXT PREVIEW NARRATIVE STRATEGIES THROUGH, QUESTION, READ, REFLECTION, RECITE, REVIEW (PQ4R) STUDENTS OF CLASS VB SDN 4 RANOMEETO}

\begin{abstract}
This research is based on the lack of reading comprehension of students in Indonesian subjects. The low ability to read students' understanding because in the learning process teachers still use conventional methods and have never used the right strategy to facilitate students in understanding and remembering a reading. The formulation of the problem in this study are; Can the Preview, Question, Read, Reflect, Recite, Review (PQ4R) strategy improve the ability to read comprehension of narrative texts on the Themes of Events in the Life of $V_{B}$ grade students at SDN 4 Ranomeeto? The aim of this study; To improve student learning outcomes in the ability to read narrative text comprehension on the theme of 7 events in the life of $V_{B}$ grade students at Ranomeeto SDN 4 through the strategies of Preview, Question, Read, Reflect, Recite, Review (PQ4R); This research was conducted in two cycles. The research subjects were 28 students of $V_{B}$ class at SDN 4 Ranomeeto in the academic year 2019/2020. This research is focused on improving students' reading comprehension ability after applying the Preview, Question, Read, Reflect, Recite, Review $(P Q 4 R)$ strategies. Data collection techniques using observation, tests, and documentation. Data analysis techniques using quantitative and qualitative descriptive analysis. The improvement of the learning process can be seen from the increase in reading comprehension of $V_{B}$ grade students with the mastery learning of students reaching $57.14 \%$ with an average student score of 59.0 in cycle I. Whereas in cycle II it reached $78.5 \%$ with an average grade students reach 78.96. Based on the results of this study it can be concluded that the strategy of Preview, Question, Read, Reflect, Recite, Review (PQ4R) can improve the learning process and the ability to read narrative text comprehension in class $V_{B}$ students of SDN 4 Ranomeeto.
\end{abstract}

Keywords: Reading Comprehension Ability; Narrative Text, PreviewStrategy; Question Read Reflect Recite Review $(P Q 4 R)$. 


\section{Pendahuluan}

Pada Era sekarang ini, sistem pendidikan nasional menghadapi tantangan yang sangat kompleks dalam menyiapkan kualitas Sumber Daya Manusia (SDM) yang mampu bersaing dalam industri 4.0. Upaya yang tepat untuk menyiapkan sumber daya manusia (SDM) yang berkualitas dan satu-satunya wadah yang dapat dipandang dan seyogiyanya berfungsi sebagai alat untuk membangun SDM yang bermutu tinggi adalah pendidikan. Oleh karena itu, pada jenjang pendidikan sekolah dasar, siswa harus diberikan keterampilan-keterampilan yang dapat meningkatkan kemampuan siswanya agar terlatih sejak dini dan dapat menjadi SDM yang berkualitas di masa yang akan mendatang. Sehingga, usaha yang paling efisien untuk mengetahui segala kejadian penting di dunia modern adalah dengan membaca. Masalah utama dalam pembelajaran pada pendidikan formal (sekolah) dewasa ini yakni masih rendahnya daya serap siswa terhadap suatu bacaan. Hal ini disebabkan karena siswa tidak memiliki kemampuan membaca yang tepat dalam membaca dan memahami isi bacaan yang telah dibacanya. Kemampuan berasal dari kata mampu yang berarti (bisa, sanggup) melakukan sesuatu, sedangkan kemampuan berarti kesanggupan, kecakapan (Rizqina, Adam, \& Chan, 2017:62). Dengan demikian, secara umum kemampuan dianggap sebagai kecakapan atau kesanggupan seseorang dalam menyelesaikan atau menyanggupi suatu pekerjaan (Sakti, 2011:69).Menurut Rikmasari \& Lestari (2018:267), bahwa kemampuan membaca pemahaman sangat penting peranannya dalam membantu anak mempelajari berbagai hal. Melalui aktivitas membaca yang baik dan benar diharapkan anak mampu mengambil inti sari bacaan yang dibacanya, sehingga mendapatkan sesuatu dari aktivitas membaca yang ia lakukan. Hal ini sejalan dengan pendapat yang dikemukakan oleh oleh Burn dalam Krismanto \& Khalik (2015:234), bahwa "kemampuan membaca merupakan kemampuan yang mutlak dikuasai oleh masyarakat yang lebih maju." Sehingga, setiap orang harus memiliki kemampuan untuk memahami suatu bacaan.Melalui kegiatan membaca pemahaman siswa mengembangkan pengetahuan dengan cara menyimak sebuah bacaan dengan maksud menangkap maksud atau ide yang tersurat maupun tersirat dari bacaan tersebut, memadukan pengetahuan awal yang sudah ada dalam diri siswa, memberikan penilaian serta kritik terhadap berbagai kesalahan yang ditemukan dalam bacaan (Rahma \& Kurnia, 2019:14).Dengan demikian, membaca pemahaman adalah kemampuan seseorang dalam memahami dan memperoleh makna dari suatu teks bacaan yang dilakukan secara cermat dengan melibatkan pengetahuan dan pengalaman pembaca untuk dihubungkan dengan isi bacaan yang bertujuan untuk menambah pengetahuan, sehingga terasa ada kepuasan tersendiri setelah bahan bacaan itu dibaca sampai selesai (Ayu, Aisha, Hendriani, \& Heryanto, 2019:330).

Permasalahan mengenai kemampuan membaca pemahaman ini terjadi di SDN 4 Ranomeeto. Berdasarkan hasil wawancara bersama guru kelas $\mathrm{V}_{\mathrm{B}}$, bahwa kemampuan membaca pemahaman siswa terutama dalam memahami bacaan teks narasi sangatlah rendah. Faktor yang menyebabkan rendahnya kemampuan membaca pemahaman teks narasi pada siswa kelas $V_{B}$ disebabkan karena beberapa faktor, yaitu : (1) belum maksimalnya minat baca siswa dan juga daya serap siswa terhadap suatu bacaan masih rendah. (2) siswa masih kesulitan dalam mengingat suatu bacaan yang terdapat dalam teks narasi. Selain itu, siswa kesulitan dalam menentukan ide pokok, membuat kesimpulan/inti sari dalam suatu bacaan. (3) siswa kurang mampu menjawab pertanyaan yang disajikan guru dan seringkali antara pertanyaan dan jawaban tidak sesuai dengan isi teks. (4) sebagian besar siswa tidak terlibat aktif saat pembelajaran berlangsung yang diakibatkan karena kurangnya strategi yang diterapkan oleh guru dalam melakukan proses pembelajaran didalam kelas. Metode yang selama ini diterapkan oleh guru masih menggunakan metode konvensional seperti ceramah, tanya jawab, dan pemberian tugas. Hal ini dibuktikan dari dokumen guru kelas $\mathrm{V}_{\mathrm{B}} \mathrm{SDN}$ 4 Ranomeeto tahun ajaran 2018/2019 yang berupa hasil ulangan tengah semester (UTS) yang menunjukkan dari 26 siswa hanya 12 orang siswa $(46,15 \%)$ yang mencapai nilai KKM. Ini menunjukkan bahwa lebih dari setengahnya atau 14 orang siswa $(53,84 \%)$ tidak mencapai nilai KKM yaitu 70 dan nilai rata-rata yang diperoleh siswa tersebut adalah 53,03. Salah satu faktor yang menjadi penyebab dari rendahnya hasil belajar siswa yaitu kemampuan siswa dalam memahami suatu bacaan masih rendah. 
Berdasarkan data tersebut di atas, dapat dikatakan bahwa pelaksanaan pembelajaran bahasa Indonesia di SDN 4 Ranomeeto belum berhasil sehingga diperlukan perbaikan proses belajar mengajar di kelas dengan diberikannya inovasi dan strategi yang tepat dalam pembelajaran membaca pemahaman siswa agar dapat meningkatkan kemampuan membaca dan memahami isi bacaan.

Salah satu strategi pembelajaran yang dapat mengatasi rendahnya kemampuan membaca pemahaman siswa memahami dan mengingatkan materi yang mereka baca adalah strategi Preview, Question, Read, Reflect, Recite, Review (PQ4R). Menurut Al-Tabany (2014:178), bahwa strategi PQ4R merupakan salah satu bagian dari strategi elaborasi. Strategi ini digunakan untuk membantu siswa mengingat apa yang mereka baca, dan dapat membantu proses belajar mengajar di kelas yang dilaksanakan dengan kegiatan membaca. Menurut Abidin (2012:100), strategi PQ4R merupakan strategi yang digunakan untuk membantu siswa mengaktifkan dirinya dalam mempelajari sebuah konsep melalui kegiatan merencanakan, memonitor, dan mengevaluasi tahapan belajar yang dilaksanakannya dengan menggunakan proses menulis sebagai alat untuk mempelajari teks bacaan. Kemudian, hal ini lebih diperkuat lagi oleh Nur Aini dalam Ardiana (2018:249), yang berpendapat bahwa "PQ4R banyak dilakukan dan terbukti efektif membantu siswa menghafal informasi dari bacaan untuk memperoleh pemahaman secara penuh."Adapun menurut Km, Jayanti, Ganing, \& Suadnyana (2014:9) strategi belajar PQ4R pada hakikatnya merupakan penimbul pertanyaan dan tanya jawab yang dapat mendorong pembaca teks melakukan pengolahan materi secara lebih mendalam dan luas. Strategi pembelajaran ini menjadikan pembelajaran berpusat pada siswa dimana siswa dirangsang untuk menyusun pengetahuannya sendiri, dapat mengembangkan keterampilan- keterampilan yang ada pada dirinya dan juga dapat memandirikan siswa serta meningkatkan kepercayaan dirinya.

Berdasarkan uraian di atas, penulis berinisiatif melakukan penelitian yang berjudul"Peningkatan Kemampuan Membaca Pemahaman Teks Narasi Melalui Strategi PQ4R Pada Tema Peristiwa dalam Kehidupan Siswa kelas V B $_{\text {B }}$ SDN 4 Ranomeeto."

\section{Metode Penelitian}

Jenis penelitian ini adalah penelitian tindakan kelas. Penelitian ini dilaksanakan di SD Negeri 4 Ranomeeto yang terletak di Jln. Sorumba, Desa Langgea, Kec. Ranomeeto, Kab. Konawe Selatan pada Semester Genap Tahun Ajaran 2019/2020. Subjek penelitian ini adalah guru dan siswa kelas $V_{B}$ SDN 4 Ranomeeto. Dimana, siswa kelas $\mathrm{V}_{\mathrm{B}}$ berjumlah 28. Jumlah laki-laki sebanyak 13 orang dan jumlah siswa perempuan sebanyak 15 orang.Adapun faktor yang akan diteliti adalah sebagai berikut : 1 . Faktor siswa yaitu a) aktivitas belajar siswa selama proses pembelajaran menggunakan strategi Preview, Question, Read, Reflect, Recite, Review (PQ4R), b) kemampuan membaca pemahaman siswa melalui strategi Preview, Question, Read, Reflect, Recite, Review. 2. Faktor guru yaitu, kemampuan guru dalam melaksanakan strategi Preview, Question, Read, Reflect, Recite, Review (PQ4R). Penelitian tindakan kelas ini dilaksanakan dalam dua siklus. Adapun prosedur penelitian tindakan ini meliputi: (1) Perencanaan, (2) Pelaksanaan Tindakan, (3) Observasi dan Evaluasi, dan (4) Refleksi dalam setiap siklus. Jenis data yaitu data kualitatif dan data kuantitatif. Data kualitatif diperoleh melalui observasi, menggunakan lembar observasi sedangkan data kuantitatif diperoleh melalui tes setiap akhir siklus tindakan. Data kualitatif akan dianalisis menggunakan deskriptif kualitatif. Sedangkan data kuantitatif akan dianalisis menggunakan deskripstif kuantitatif.

\section{Hasil Penelitian}

1. Aktivitas Mengajar Guru

Pada siklus I guru harus lebih pandai dalam menguasai kondisi kelas dan mendorong siswa agar lebih aktif dalam proses pembelajaran dengan memberikan kesempatan kepada siswa untuk melakukan tanya jawab dalam bertukar informasi bersama temannya, guru harus membimbing siswa dalam membaca sekilas teks bacaan agar siswa tidak kebingungan dalam menentukan ide pokok dari teks bacaan dan mampu dalam menyusun pertanyaan sendiri menggunakan kata tanya yang tepat, guru harus memperhatikan dan menentukan alokasi waktu untuk tahapan membaca sekilas teks bacaan dan membaca secara detail bahan bacaan agar waktu 
tidak dihabiskan pada tahap membaca (read). Serta guru harus lebih membangun keberanian dan kepercayaan diri siswa ketika presentasi ke depan kelas. Sedangkan, pada siklus II sudah terbukti adanya peningkatan apabila dibandingkan dengan pembelajaran pada siklus I. Dimana, guru sudah lebih terampil dalam mengkondisikan kelas sehingga kelas tidak ribut selama proses pembelajaran, guru sudah mampu membuat siswa terlibat aktif dalam pembelajaran yang ditunjukan dengan antusias siswa dalam memberikan tanggapan dan tanya jawab kepada setiap kelompok yang maju ke depan kelas, guru sudah optimal dalam membimbing siswa dalam membaca sekilas dan membaca secara detail bahan bacaan sehingga hanya ada beberapa siswa saja yang masih merasa kebingungan. Selain itu, guru sudah mampu mengatur waktu untuk setiap tahapan strategi PQ4R terutama pada tahap preview dan tahap read. Untuk lebih jelasnya dapat ditunjukkan pada Tabel 1 berikut :

Tabel 1. Rekapitulasi aktivitas Guru Pada Siklus I dan Siklus II

\begin{tabular}{cccccc}
\hline Uraian & \multicolumn{2}{c}{ Siklus I } & \multicolumn{2}{c}{ Siklus II } \\
\cline { 2 - 6 } & P1 & & P2 & P1 & P2 \\
\hline Skor Perolehan & 9 & & 10 & 14 & 14 \\
\hline Rata-rata & \multicolumn{2}{c}{9,5} & & \multicolumn{2}{c}{14} \\
\hline Presentase (\%) & \multicolumn{2}{c}{$67,85 \%$} & & \multicolumn{2}{c}{$100 \%$} \\
\hline
\end{tabular}

Ket: P1 = Pertemuan Pertama, P2 = Pertemuan Kedua

\section{Aktivitas Belajar Siswa}

Pada siklus I ada beberapa yang tidak terlaksana yaitu : 1) Siswa masih kebingungan dalam menentukan ide pokok dari teks bacaan yang ada di dalam LKS, 2) Siswa masih kesulitan dalam menyusun pertanyaan menggunakan aspek apa, siapa, kapan, dimana, mengapa dan bagaimana, 3) Siswa tidak mampu memahami setiap makna bacaan yang ada di dalam LKS, 4) Siswa belum bisa memberikan tanggapan atau melakukan tanya jawab kepada temannya yang maju di depan kelas.

Pada Siklus II aktivitas belajar siswa menggunakan strategi Preview, Question, Read, Reflect, Recite, Review (PQ4R) terbukti adanya peningkatan dari siklus I. Walaupun masih ada sebagian kecil siswa yang masih kebingungan dalam membuat pertanyaan dan membuat kesimpulan/inti sari dari teks bacaan yang disebabkan karena faktor internal siswa yaitu siswa masih terbata-bata dalam membaca sehingga siswa kesulitan dalam memahami isi bacaan yang dibacanya.Untuk lebih jelasnya dapat dilihat pada Tabel 2 berikut.

Tabel2. Rekapitulasi Aktivitas Siswa pada Siklus I dan Siklus II

\begin{tabular}{|c|c|c|c|c|}
\hline \multirow[t]{2}{*}{ Uraian } & \multicolumn{2}{|c|}{ Siklus I } & \multicolumn{2}{|c|}{ Siklus II } \\
\hline & P1 & P2 & P1 & P2 \\
\hline Jumlah & 9 & 10 & 14 & 14 \\
\hline Rata-Rata & \multicolumn{2}{|c|}{9,5} & \multicolumn{2}{|c|}{14} \\
\hline Presentase (\%) & \multicolumn{2}{|c|}{$67,85 \%$} & \multicolumn{2}{|c|}{$100 \%$} \\
\hline
\end{tabular}

\section{Ket $:$ P1 = Pertemuan Pertma; P2 = Pertemuan Kedua}

\section{Hasil Belajar Siswa}

Berdasarkan hasil tes siklus I, dari 28 orang siswa yang mengikuti tes terdapat 16 orang siswa yang memiliki nilai dengan kategori tuntas (memperoleh $\geq 70$ ) dengan presentase $57,14 \%$ sedangkan 12 orang lainnya belum tuntas (memperoleh $\leq 70$ ) dengan presentase $42,85 \%$ dengan nilai rata-rata siswa sebesar 59,0. Sedangkan, pada siklus II terdapat 28 siswa yang telah memenuhi kriteria ketuntasan belajar. Dengan ketuntasan klasikal sebesar 78,5\% dengan nilai rata-rata siswa sebesar 78,96. Sehingga, dapat dikatakan bahwa pada siklus II sebagian besar siswa sudah dapat memahami isi bacaan dengan baik terutama dalam membuat pertanyaan, menjawab bertanyaan 
berdasarkan teks, menentukan ide pokok, menemukan dan mengartikan kata-kata sulit dam menceritkaan kembali isi bacaan.Untuk lebih jelasnya dapat dilihat pada Tabel 3 di bawah ini.

Tabel 3. Hasil Tes Kemampuan Membaca Pemahaman Siswa Siklus I dan Siklus II

\begin{tabular}{lcc}
\hline \multicolumn{1}{c}{ Pencapaian } & \multicolumn{2}{c}{ Siklus } \\
\cline { 2 - 3 } & $\mathbf{1}$ & $\mathbf{2}$ \\
\hline Jumlah Siswa & 28 orang & 28 orang \\
\hline Nilai Tertinggi & 79 & 91,6 \\
\hline Nilai Terendah & 33,3 & 50 \\
\hline Nilai Rata-Rata & 59,0 & 78,96 \\
\hline \% Tuntas & $57,14 \%$ & $78,57 \%$ \\
\hline \% Tidak Tuntas & $42,85 \%$ & $21,42 \%$ \\
\hline
\end{tabular}

\section{Pembahasan}

\section{Aktivitas Mengajar Guru}

Berdasarkan analisis guru selama kegiatan penelitian ini yang terdiri dari dua siklus yang masing-masing siklus terdiri dari dua kali pertemuan diperoleh gambaran bahwa selama proses pembelajaran dengan menggunakan strategi preview, question, read, reflect, recite, review (PQ4R) ditemukan bahwa masih ada beberapa aktivitas guru yang belum terlaksana pada siklus I (satu) yaitu guru belum membimbing siswa dalam membaca sekilas dan juga guru belum mampu mengaktifkan siswa dalam belajar terutama dalam memberikan kesempatan kepada siswa untuk memberikan tanggapan dan tanya jawab kepada temannya. Sehingga, hal ini berdampak pada rendahnya hasil belajar siswa dalam memahami isi bacaan.

Oleh karena itu, penelitian ini dilanjutkan pada tindakan siklus II (dua) dimana guru lebih membimbing dan memotivasi siswa agar lebih aktif dalam belajar terutama untuk menentukan ide pokok dan membuat pertanyaan menggunakan kata tanya apa, siapa, kapan, dimana, mengapa dan bagaimana serta guru lebih menjalin hubungan yang simpatik dengan siswa agar terciptanya suasana belajar yang penuh kasih dan sayang. Hal ini sejalan dengan pendapat yang dikemukakan Kardi dan Nur dalam Al-Tabany (2014:22) bahwa guru yang efektif ialah orang-orang yang dapat menjalin hubungan simpatik dengan para siswa, menciptakan lingkungan kelas yang mengasuh, penuh perhatian, memiliki suatu rasa cinta belajar, menguasi sepenuhnya bidang studi mereka, dan dapat memotivasi siswa untuk bekerja tidak sekedar mencapai suatu prestasi namun juga menjadi anggota masyarakat yang pengasih. Kemudian, bimbingan guru dalam hal ini lebih difokuskan pada bimbingan belajar, yakni proses pemberian bantuan secara terus menerus dan sistematis oleh guru kepada siswa dalam rangka memecahkan kesulitan belajar yang dihadapi, sehingga siswa memiliki kemampuan untuk mencapai keberhasilan dalam belajar (Sukirman, 2011:24).

\section{Aktivitas Belajar Siswa}

Berdasarkan hasil analisis data dan observasi siswa selama proses pembelajaran siklus I dan siklus II menunjukkan gambaran bahwa pembelajaran kemampuan membaca pemahaman teks narasi pada siswa kelas $\mathrm{V}_{\mathrm{B}}$ SD Negeri 4 Ranomeeto terjadi peningkatan. Aktivitas belajar siswa dianggap baik walaupun masih ada beberapa kekurangan-kekurangan. Analisis hasil observasi kegiatan siswa dalam pembelajaran menunjukkan bahwa penggunaan strategi preview, question, read, reflect, recite, review (PQ4R) memiliki dampak yang positif dalam meningkatkan kemampuan membaca pemahaman teks narasi siswa. Keberhasilan aktivitas belajar siswa dipengaruhi oleh aktivitas mengajar guru. Hasil observasi aktivitas belajar siswa pada siklus I menunjukkan bahwa sebagian besar siswa belum mampu membuat pertanyaan menggunakan kata tanya apa, siapa, kapan, mengapa dan bagaimana dengan baik. Selain itu, siswa belum mampu menentukan ide pokok dari teks bacaan yang mereka baca secara sekilas (preview). Sehingga, setiap kekurangan-kekurangan itu dilanjutkan pada siklus II agar lebih efektif. 
Melalui strategi preview, question, read, reflect, recite, review (PQ4R) pada siklus II ini siswa menjadi lebih aktif dalam kegiatan membaca karena dalam strategi ini ada tahapan membaca sekilas dan ada tahapan membaca secara detail bahan bacaan sehingga membuat siswa lebih terbiasa dalam membaca. Selain itu, di dalam strategi preview, question, read, reflect, recite, review (PQ4R) ada tahapan membuat pertanyaan sehingga mendorong siswa untuk lebih aktif dalam menjawab sejumlah pertanyaan yang telah dibuatnya. Dengan demikian, strategi ini dapat membuat siswa lebih teliti dan berhati-hati dalam membaca. Hal ini sejalan dengan pernyataan yang dikemukakan oleh Al-Tabany (2014:180) pengalaman telah menunjukkan bahwa apabila seseorang membaca untuk menjawab sejumlah pertanyaan, maka akan membuat dia membaca lebih berhati-hati serta seksama akan dapat membantu mengingat apa yang dibaca dengan baik. Based on the statements above reading comprehension is a way to understanding or comprehend of the text that includes not only word reading, world knowledge or fluency, but by reading comprehension people can get information and wide insight from the text(Martina, As, \& Yulianan, 2018:19).

\section{Hasil Belajar Siswa (Kemampuan Membaca Pemahaman)}

Berdasarkan hasil observasi yang dilakukan oleh peneliti sebelum diterapkannya strategi preview, question, read, reflect, recite, review (PQ4R) ditemukan rendahnya hasil belajar siswa yang ditunjukkan dari dokumen guru yang berupa hasil ulangan tengah semester siswa pada tahun 2018/2019. Dimana, dari 26 orang siswa terdapat 46,15\% yang mencapai KKM. Ini menunjukkan bahwa lebih dari setengahnya atau 14 orang siswa $(53,84 \%)$ tidak mencapai nilai KKM yaitu 70 dan nilai rata-rata yang diperoleh siswa tersebut adalah 53,03. Setelah diterapkannya strategi preview, question, read, reflect, recite, review (PQ4R) telah terbukti adanya peningkatan.

Hal ini ditunjukkan dari hasil tes kemampuan membaca pehamaman siswa pada siklus I, secara klasifikasi dengan presentase ketuntasan yaitu 57,14\% atau 16 orang siswa yang tuntas dan siswa yang tidak tuntas berjumlah 12 orang dengan presentase ketuntasan $42,85 \%$. Ketuntasan ini belum mencapai indikator keberhasilan dari penelitian ini yaitu $75 \%$. Rendahnya hasil belajar siswa ini disebakan karena belum optimalnya guru dalam mengajar serta rendahnya aktivitas siswa dalam proses pembelajaran dengan menggunakan strategi preview, question, read, reflect, recite, review (PQ4R) sehingga masih banyaknya kekurangan-kekurangan guru maupun siswa dalam proses pembelajaran. Sedangkan pada siklus II ketuntasan siswa telah mencapai 78, 57\% atau 6 orang siswa tidak tuntas, dengan nilai rata-rata 78,96.

Berdasarkan tes hasil belajar (kemampuan membaca pemahaman siswa) yang dicapai oleh siswa pada siklus II telah mengalami peningkatan sebesar 21,42\% yaitu dari 57,14\% siswa yang tuntas meningkat menjadi $78,57 \%$. Terjadinya peningkatan presentase ketuntasan pada siklus II penelitian ini dianggap telah berhasil mencapai target yang diharapkan oleh peneliti yaitu $75 \%$ (mencapai KKM 70). Untuk lebih jelasnya dapat dilihat pada Gambar 1 berikut : 


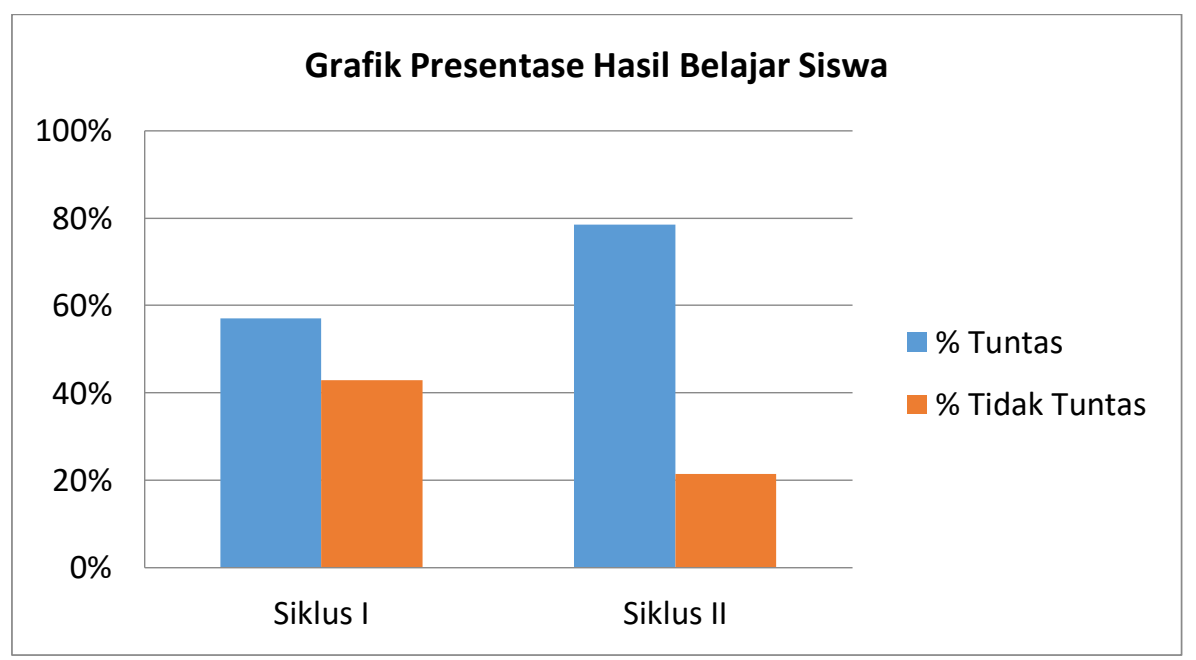

Gambar 1. Grafik Perbandingan Peningkatan Kemampuan Membaca Pemahaman Siswa Siklus I dan Siklus I

Berdasarkan data hasil evaluasi di atas, menunjukkan bahwa strategi preview, question, read, reflect, recite, review (PQ4R) dapat meningkatkan hasil belajar (kemampuan membaca pemahaman teks narasi siswa). Thomas dan Robinsondalam Putri et al. (2019:12)menyatakan bahwa proses belajar dengan menggunakan strategi PQ4R ini akan meningkatkan kemampuan membaca pemahaman yang tinggi yang dilandasi oleh konsentrasi yang baik pada saat membaca, dan mampu digunakan untuk mengingat informasi dalam jangka waktu yang cukup lama. Hal ini sejalan dengan pendapat yang dikemukakan oleh Al-Tabany (2014:181) yang menjelaskan bahwa strategi belajar PQ4R ini dapat membantu siswa memahami materi pembelajaran, terutama terhadap materi yang lebih sukar dan menolong siswa untuk berkonsentrasi lebih lama. Dengan demikian, strategi ini dapat membantu siswa mengingat dan memahami apa yang mereka baca, dan membantu pemindahan informasi baru dari memori jangka pendek ke memori jangka panjang sehingga hal ini berdampak pada peningkatan hasil belajar siswa pada setiap siklusnya. Selain itu, pengalaman awal bisa dibangun melalui aktivitas membaca. Dengan kegiatan ini siswa akan memiliki stock of knowledge (Suprijono, 2015:122).

\section{Simpulan}

Berdasarkan pembahasan dan analisis data dapat disimpulkan bahwa pelaksanaan pembelajaran dengan menggunakan strategi preview, question, read, reflect, recite, review (PQ4R) dapat meningkatkan hasil belajar (kemampuan membaca pemahaman teks narasi) siswa kelas $\mathrm{V}_{\mathrm{B}}$ SD Negeri 4 Ranomeeto. Setelah dilaksanakannya siklus I dan siklus II ditemukan adanya peningkatan kemampuan membaca pemahaman siswa terutama dalam hal menentukan ide pokok, membuat pertanyaan menggunakan kata tanya, menjawab pertanyaan berdasarkan teks, mengartikan dan menemukan kata-kata sulit serta membuat kesimpulan/inti sari dari bacaan. Peningkatan tersebut dapat ditunjukkan dengan nilai presentase ketuntasan belajar siswa pada setiap siklus. Dimana, presentase ketuntasan secara klasikal pada siklus I mencapai 57,14\% dengan nilai rata-rata 59,0. Hal ini menunjukkan bahwa presentase hasil belajar yang dicapai pada siklus I dikategorikan rendah dan belum mencapai target yang ditetapkan dalam penelitian ini yaitu sebesar $75 \%$. Sehingga, penelitian ini dilanjutkan pada siklus II dan hasilnya meningkat dengan ketuntasan belajar klasikal mencapai $78,5 \%$ dengan nilai rata-rata siswa 78,96. Keberhasilan belajar siswa tidak luput dari aktivitas mengajar guru dan aktivitas belajar siswa yang telah terlakasana dengan baik. Dengan demikian, penggunaan strategi preview, question, read, reflect, recite, review (PQ4R) dapat meningkatkan aktivitas dan kemampuan membaca pemahaman teks narasi siswa kelas $\mathrm{V}_{\mathrm{B}} \mathrm{SD}$ Negeri 4 Ranomeeto. 
Jurnal Ilmiah Pembelajaran Sekolah Dasar

Volume 2 Nomor 1 - Februari 2020, e-ISSN 2656-0402

Available online at:http://ojs.uho.ac.id/index.php/jipsd

\section{Daftar Pustaka}

Abidin, Y. (2012). Pembelajaran Membaca Berbasis Pendidikan Karakter. Bandung: PT Refika Aditama

Al-Tabany, T. I. B. (2014) Mendesain Model Pembelajaram Inovatif, Progresif, Dan Kontekstual. Jakarta: Kencana.

Ardiana, R. (2018). Pengaruh Metode Pembelajaran Pq4r Berbantu Media Flipcart Terhadap Kemampuan Menemukan Pokok Pikiran Paragraf Siswa Kelas Iv Sdn Brambang Tahun 2017/2018. 245-259.

Ayu, A., Aisha, N., Hendriani, A., \& Heryanto, D. (2019). Penerapan Strategi Pq4r Dalam Meningkatkan Keterampilan Membaca Pemahaman Siswa Kelas V Sd. JPGSD, 4(I), 329-339.

Km, N., Jayanti, M., Ganing, N. N., \& Suadnyana, I. N. (2014). Pengaruh Strategi Belajar Preview , Question, Read, Reflect, Recite, Review Terhadap Hasil Belajar Bahasa Indonesia Kelas V Sd 13 Pemecutan. Jurnal PGSD Universitas Pendidikan Ganesha, 2(1), 1-10.

Krismanto, W., \& Khalik, A. (2015). Meningkatkan Kemampuan Membaca Pemahaman Melalui Metode Survey, Question, Read, Recite, Review ( Sq3r) Pada Siswa Kelas Iv Sd Negeri 46 Parepare. Jurnal Publikasi Pendidikan, 5(3), 234-242.

Martina, D. E., As, I., \& Yulianan. (2018). The Effect of Using PQ4R (Preview, Question, Read, Reflect, Recite, Review) Strategy on EFL Students' Reading Comprehension. Research in English and Education (READ), 3(February), 17-24.

Putri, A. K., Fitriani, A. D., \& Mulyasari, E. (2019). Penerapan Strategi Pq4r Untuk Meningkatkan Keterampilan Membaca Pemahaman Siswa Kelas Iii Sd. JPGSD, 4(I), 1-14.

Rizqina, Z. A., Adam, M., \& Chan, S. (2017). Pengaruh Budaya Kerja, Kemampuan, Dan Komitmen Kerja Terhadap Kepuasan Kerja Pegawai Serta Dampaknya Terhadap Kinerja Badan Pengusahaan Kawasan Perdagangan Bebas Dan Pelabuhan Bebas Sabang (Bpks). Jurnal Magister Manajemen, 1(1), 59-69.

Rikmasari, R., \& Lestari, M. (2018). Metode Pembelajaran Pq4r Dalam Peningkatan Kemampuan Membaca Pemahaman Siswa Kelas V Di Bekasi.Journal of Madrasah Ibtidaiyah Education, 2(2), 265-275.

Sakti, I. (2011). Korelasi Pengetahuan Alat Praktikum Fisika Dengan Kemampuan Psikomotorik Siswa Di Sma Negeri Q Kota Bengkulu. Jurnal Exacta, 9(1), 67-76.

Sukirman. (2011). Peranan Bimbingan Guru Dan Motivasi Belajar Dalam Rangka Meningkatkan Prestasi Belajar Peserta Didik Sma Negeri 1 Metro Tahun 2010. Guidena, 1(1), 23-35.

Suprijono, A. (2015). Cooperative Learning Teori \& Aplikasi Paikem. Yogyakarta: Pustaka Pelajar. 